\title{
RANCANG BANGUN DAN BASIS DATA \\ PADA KLINIK 24 JAM \\ SECARA KONSEPTUAL DAN LOGIKAL
}

\author{
Wihendro; Indrajani; Safan Capri \\ Information Systems Department, School of Information Systems, Binus University \\ Jl. K.H. Syahdan No. 9, Palmerah, Jakarta Barat 11480 \\ wihendro@binus.ac.id
}

\begin{abstract}
The aim of this research is to design a database model which is conceptual and logical for a 24-hour clinic. The methods used in this research are the data collection through literature studies, surveys, and interviews to the clinic management to get a description of the business processes implemented at a 24-hour clinic. Then we use the conceptual database design method which identifies important entities, relationships entities, and existing attributes. After that, we create a database logical model which represents the clinical database 24 hours. From that, the model is expected to be a logical database model for further development into a clinical application 24 hours to improve the health services to the public.
\end{abstract}

Keywords: database, models, conceptual, logical, 24 hours clinic

\begin{abstract}
ABSTRAK
Tujuan penelitian ini adalah merancang suatu model basis data konseptual dan logikal untuk klinik 24 jam. Metode yang digunakan dalam penelitian ini adalah pengumpulan data dengan studi kepustakaan, survei, dan wawancara ke pengelola klinik untuk mendapatkan deskripsi bisnis proses klinik 24 jam yang diterapkan. Kemudian menggunakan metode perancangan konseptual basis data, yang mengidentifikasi entitas penting, hubungan antar entitas, dan attribute-attribute yang ada. Dilanjutkan dengan membuat model logikal basis data yang merepresentasikan basis data klinik 24 jam. Dari model logikal tersebut diharapkan menjadi model basis data untuk dikembangkan lebih lanjut menjadi sebuah aplikasi klinik 24 jam untuk meningkatkan layanan kesehatan kepada masyarakat
\end{abstract}

Kata kunci: basis data, model, konseptual, logikal, klinik 24 jam 


\section{PENDAHULUAN}

Kemudahan akses terhadap layanan publik kesehatan menjadi faktor penunjang kehidupan yang penting dalam kehidupan sehari - hari masyarakat. Hal ini berarti masyarakat membutuhkan tempat - tempat yang dapat memberikan layanan kesehatan, baik berupa rumah sakit (pemerintah, perusahaan, dan swasta/lainnya), puskesmas, maupun klinik 24 jam yang dapat dengan mudah diakses oleh masyarakat. Berdasarkan data dari Badan Pusat Statistik (http://sp2010.bps.go.id/index.php, 2011), jumlah penduduk Indonesia mencapai 237.641.326 di tahun 2010, dengan jumlah penduduk miskin di Indonesia pada tahun 2010 sebesar 31.023.400 orang (13,05\%). Dari tahun 1999 hingga2006, rata-rata pertumbuhan jumlah rumah sakit swasta di Indonesia mencapai sekitar 4\% pertahun, padahal jumlah rumah sakit pemerintah hanya meningkat rata-rata 2,5\% setiap tahunnya.Demikian halnya dengan klinik kesehatan. Sebagai contoh, di DKI Jakarta, dari tahun 2002 sampai 2006 jumlah klinik umum dan spesialis tumbuh cukup pesat dengan rata-rata laju pertumbuhan 10,4\% setiap tahunnya. Dalam tahun 2007, di DKI Jakarta, estimasi rata-rata jumlah kunjungan pasien ke klinik umum dan spesialis kelasmenengah ke atas mencapai 667 pasien per klinik per bulan(Mansur, 2008).Untuk daerah Bantenpada tahun 2008 jumlah poliklinik sebanyak 427 dengan jumlah desa 1504 (Statistik Indonesia, 2011).

Menurut Peraturan Menteri Kesehatan, berdasarkan jenis pelayanannya, klinik dibagi menjadi Klinik Pratama dan Klinik Utama(Peraturan Menteri Nomor 028/MENKES/I/2011, 2011).Klinik Pratama merupakan klinik yang menyelenggarakan pelayanan medik dasar yang dilayani oleh dokter umum dan dipimpin oleh seorang dokter umum. Berdasarkan perijinannya klinik ini dapat dimiliki oleh badan usaha ataupun perorangan. Adapun Klinik Utama merupakan klinik yang menyelenggarakan pelayanan medik spesialistik atau pelayanan medik dasar dan spesialistik. Spesialistik berarti mengkhususkan pelayanan pada satu bidang tertentu berdasarkan disiplin ilmu, golongan umur, organ atau jenis penyakit tertentu.Klinik ini dipimpin seorang dokter spesialis ataupun dokter gigi spesialis. Berdasarkan perijinannya klinik ini hanya dapat dimiliki oleh badan usaha berupa CV, ataupun PT.

Pertumbuhan jumlah klinik di daerah-daerah pinggiran kota perlu ditunjang pula dengan sarana dan prasana yang memadai untuk memberikan layanan kesehatan kepada masyarakat. Untuk meningkatkan layanan kesehatan kepada masyarakat maka diperlukan basis data klinik 24 jam yang dapat membantu menyimpan data pasien, obat,pengobatan pasien, dan jadwals praktek dosen.

Bagi banyak klinik 24 jam di daerah-daerah pinggiran kota, pemanfaatan teknologi informasi untuk menunjang pelaksanaan operasional sehari-haribelum dimanfaatkan secara maksimal.Pengolahan data yang dilakukanyang memanfaatkan Microsoft Excel dan Word mengakibatkan terjadinya kesulitan dalam mencari data-data pasien maupun riwayat penyakit pasien.Selain itu adanya keterbatasan sumber daya dan dana yang ada, yang menyebabkan pihak pengelola klinik, ragu dalam membangunmodelbasis datasebagai pendukung utama dalam sistem informasi kesehatan.Oleh karena itu penelitian ini dimulai dengan membuat model konseptual dan logikal basis data klinik 24 jam dimana hasil penelitian ini dapat dimanfaatkan oleh pengelola untuk menekan biaya pengembangan sistem informasi.

\section{METODE}

Metode penelitian yang digunakan adalah metode pengumpulan data, metode analisis, dan metode perancangan basis data. Teknik yang digunakan dalam metode pengumpulan data ini mencakup antara lain wawancara, mempelajari dokumen, observasi, dan studi kepustakaan (Indrajani, 
2011). Wawancara dilakukan pada bagian-bagian yang akan menggunakan sistem basis data yang diusulkan, yaitu bagian administrasi, dokter, perawat, pasien dan karyawan. Pertanyaan-pertanyaan yang akan ditanyakan akan disiapkan terlebih dahulu sebelum wawancara berlangsung. Sifat yang akan digunakan adalah gabungan antara pertanyaan tertutup dan terbuka. Untuk mendapatkan data dan informasi mengenai kebutuhan pengguna secara lengkap, maka dilakukan juga pengumpulan dokumen-dokumen berupa contoh-contoh formulir seperti registrasi pasien, pendataan transaksi yang terjadi seperti penembusan resep dokter, laporan-laporan medis pasien, buku pasien, dan daftar-daftar seperti dokter, karyawan, dan pasien. Selain itu juga dilakukan observasi langsung ke lapangan agar memahami sistem pada klinik secara nyata.

Metode berikutnya adalah metode analisis, di mana dilakukan analisis kebutuhan data dan kelemahan dari sistem yang sedang berjalan.Dari hasil analisis yang dilakukan terhadap suatu klinik maka dapat dirumuskan beberapa masalah yaitu kesulitan pencarian data-data pasien, dokter, karyawan, persediaan maupun transaksi-transaksi.Klinik menyimpan data-data pasien yang berobat di klinik.Selain itu klinik juga menyimpan data-data transakasi yang telah dilakukan klinik sehingga semakin lama data-data yang disimpan semakin banyak.Akibatnya, pengguna informasi membutuhkan waktu yang lama untuk mendapatkan informasi yang dibutuhkan.Masalah lainnya adalah kesulitan membuat dan menyajikan laporan, pasien berobat, dan transaksi yang cukup banyak dilakukan secara manual sehingga membutuhkan waktu yang cukup lama untuk mengolah informasi yang dibutuhkan.Kemudian belum adanya sistem keamanan data.Data-data hanya tercatat pada buku-buku dan berkas-berkas sehingga data-data penting klinik dapat dilihat, diganti dan diambil oleh siapa saja.Lalu kesalahan pemasukan data.Sistem yang berjalan pada klinik masih manual, ada kemungkinan kesalahan manusia penulisan data.

Metode terakhir yang digunakan dalam penelitian ini adalah metode perancangan basis data. Dalam metode ini akan dibagi menjadi 3 tahap yaitu (Indrajani, 2010), yaitu perancangan basis data konseptual, perancangan basis data logikal, dan perancangan basis data fisikal. Adapun perancangan basis data konseptual adalah perancangan basis-data konseptual proses membangun suatu model dari informasi yang digunakan dalam sebuah perusahaan, terbebas dari segala pertimbangan fisikal. Perancangan basis-data logikal yaitu proses membangun suatu model dari informasi yang digunakan dalam sebuah perusahaan berdasarkan sebuah model data yang spesifik tetapi terbebas dari DBMS tertentu dan pertimbangan fisikal lainnya. Tahapan ketiga yaitu perancangan basis-data fisikal adalah proses menghasilkan sebuah deskripsi dari implementasi basis-data pada media penyimpanan sekunder yang mendeskripsikan relasi dasar, organisasi file, dan indeks yang digunakan untuk mengakses data secara efisien, dan setiap batasan integritas terkait dan ukuran-ukuran keamanan.

Metode perancangan basis data dalam penelitian ini terangkum pada Gambar 1.

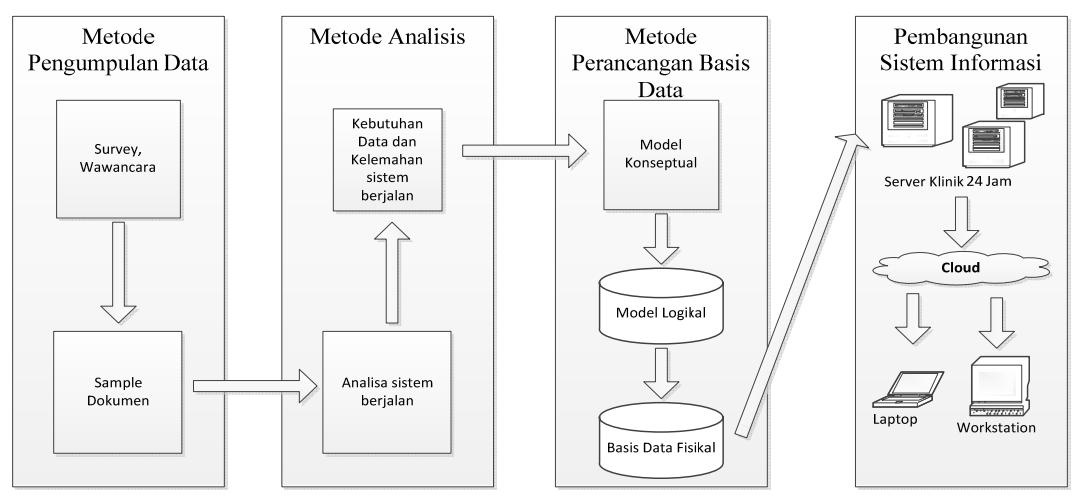

Gambar 1 Integrasi perancangan model konseptual, logikal dan fisikal basis data dengan pembangunan Sistem Informasi Klinik 24 Jam 


\section{HASIL DAN PEMBAHASAN}

\section{Pengumpulan Data}

Pengumpulan data dilakukan dengan mengobservasi langsung terhadap proses kerja di klinik Sarana Medika baru. Dokumen-dokumen pendukung dikumpulkan selama observasi untuk mengidentifikasi informasi-informasi yang akan direkam kedalam sistem. Selain itu, dilakukan pula wawancara langsung dengan user-user terkait untuk mendapatkan gambaran awal bisnis proses yang berjalan.

\section{Definisi Sistem}

Sistem ini mencakup pemeriksaan pasien, tebus obat, pembayaran, pemesanan obat, dan penyesuaian obat (Gambar 2). Dengan keterangan sebagai berikut: (1) pasien berhubungan dengan dokter, petugas klinik, tebus obat; (2) keuangan memberikan laporan kepada Direktur Klinik, dan berhubungan dengan Pemasok Obat, Petugas Klinik dan Gudang; (3) dokter berhubungan dengan pasien dan perawat; (4) petugas klinik berhubungan dengan pasien, Tebus Obat, Gudang, dan Keuangan; (5) pasien, Direktur Klinik, Asuransi dan Pemasok Obat tidak mengakses system, karena ketiganya ditempatkan di luar batasan sistem. Analisis dan pengumpulan kebutuhan disajikan pada Tabel 1.

\section{Desain Basis Data}

\section{Perancangan Konseptual}

Proses membangun sebuah rancangan informasi yang digunakan dalam suatu perusahaan yang bebas dari pertimbangan fisikal. Perancangan melibatkan pembuatan suatu model data konseptual dari bagian perusahaan.Model data dibuat dengan menggunakan informasi yang didokumentasi dalam spesifikasi kebutuhan pengguna.Perancangan basis data konseptual secara keseluruhan bebas dari rincian implementasi seperti software DMBS, program aplikasi, bahasa pemrograman, hardware platform, atau permasalahan fisikal lainnya. Langkah-langkah dalam perancangan basis data konseptual, antara lain mengidentifikasi tipe entitas, mengidentifikasi tipe relationship, identifikasi dan asosiasi atribut suatu entitas, menentukan domain atribut, identifikasi candidate key dan primary key suatu entitas, mengecek model redundansi, dan validasi model konseptual terhadap transaksi pengguna. Identifikasi identitas dapat dilihat pada Tabel 2. Identifikasi tipe hubungan dapat dilihat pada Tabel 3. Gambar 3 dan 4 berikut ini merupakan ERD konseptual dan logikal yang dibuat.

\section{Perancangan Logikal}

Proses membangun sebuah rancangan informasi yang digunakan dalam suatu perusahaan berbasis data pada rancangan data yang spesifikasi tetapi masih bebas dari penentuan DBMS dan pertimbangan fisikal yang lain. Pada proses perkembangan model data logikal, model diuji dan divalidasi terhadap kebutuhan pengguna. Tujuan dari tahapan ini adalah untuk menghilangkan fiturfitur yang tidak kompatibel dengan model relasional.Pada akhir tahapan ini dihasilkan satu model data logikal. Adapun langkah-langkah yang dilakukan dalam merancang basis-data logikal, yaitu menurunkan tabel untuk model data logikal, memvalidasi tabel menggunakan normalisasi, memvalidasi tabel terhadap transaksi pengguna, memeriksa batasan integritas, dan me-review model data logikal lokal dengan pengguna. 


\section{PENUTUP}

Kesimpulan yang didapat dari penelitian ini adalah dihasilkannya model logika dasar yang terdiri dari 9 tabel yang sifatnya adalah tabel master dan 10 tabel yang sifatnya adalah transaksi untuk klinik 24 jam. Tabel-tabel tersebut dapat digunakan sebagai acuan awal untuk merancang layar masukan dan keluaran sistem informasi klinik 24 jam. Saran dari penelitian ini adalah dapat dilanjutkan kembali penelitian ini untuk memperluas lingkup sistem klinik 24 jam. Beberapa bisnis proses area yang masih dapat dipelajari adalah kerjasama dengan asuransi, sistem penggajian dokter dan karyawan. Dilanjutkan pula dengan merancang sistem sederhana klinik 24 jam.

\section{DAFTAR PUSTAKA}

BPS. (2010). Sensus Penduduk. Diakses dari http://sp2010.bps.go.id/index.php.

BPS. (2011). Statistika Indonesia. Diakses dari http://www.bps.go.id/flip/flip11/index3.php.

Indrajani. (2010). Analisis dan perancangan sistem basis data pada rumah sakit. Comtech, 1 (1). Jakarta: Universitas Bina Nusantara.

Indrajani. (2011). Perancangan Basis Data dalam All In 1. Jakarta: Elex Media Computindo.

Mansur, S. (2008). Prospek Usaha Klinik Kesehatan Di Indonesia Januari 2008. PT MEDIA DATA RISET. diunduh dari http://mediadata.co.id/MCSIND-2008/Prospek-Usaha-Klinik-Kesehatandi-Indonesia-2008.pdf.

\section{APPENDIX}

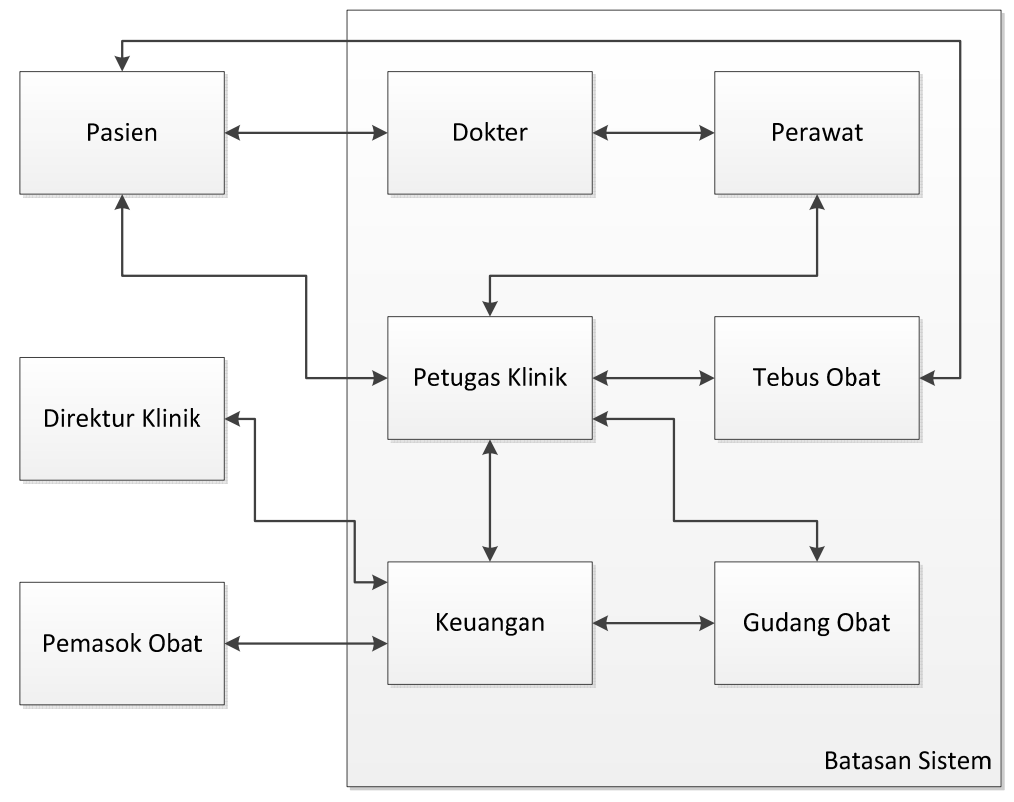

Gambar 2 Definisi sistem 
Tabel 1 Analisis dan Pengumpulan Kebutuhan

\begin{tabular}{|c|c|c|c|c|c|c|c|}
\hline Data & Tipe akses & Petugas klinik & Perawat & Dokter & Tebus Obat & Keuangan & Gudang \\
\hline \multirow[b]{4}{*}{ Pasien } & Query & $\mathrm{V}$ & & $\mathrm{V}$ & & & \\
\hline & View & V & V & V & & & \\
\hline & Surat & & & $\mathrm{V}$ & & & \\
\hline & Laporan & & $\mathrm{V}$ & $\mathrm{V}$ & & & \\
\hline \multirow[b]{4}{*}{ Pemasok obat } & Query & & & & & & $\mathrm{V}$ \\
\hline & View & & & & & & $\mathrm{V}$ \\
\hline & \begin{tabular}{|l|} 
Surat \\
\end{tabular} & & & & & & $\mathrm{V}$ \\
\hline & Laporan & & & & & & $\mathrm{V}$ \\
\hline \multirow[b]{4}{*}{ Obat } & Query & & & $\mathrm{V}$ & $\mathrm{V}$ & & $\mathrm{V}$ \\
\hline & View & & $\mathrm{V}$ & $\mathrm{V}$ & $\mathrm{V}$ & & $\mathrm{V}$ \\
\hline & Surat & & & $\mathrm{V}$ & $\mathrm{V}$ & & $\mathrm{V}$ \\
\hline & Laporan & & & $\mathrm{V}$ & $\mathrm{V}$ & & $\mathrm{V}$ \\
\hline \multirow[b]{4}{*}{ Pemeriksaan Pasien } & Query & & $\mathrm{V}$ & $\mathrm{V}$ & & & \\
\hline & \begin{tabular}{|l|} 
View \\
\end{tabular} & & & $\mathrm{V}$ & & & \\
\hline & \begin{tabular}{|l|} 
Surat \\
\end{tabular} & & & $\mathrm{V}$ & & & \\
\hline & Laporan & & & $\mathrm{V}$ & & & \\
\hline \multirow[b]{4}{*}{ Tebus Obat } & Query & & & & $\mathrm{V}$ & & \\
\hline & View & & & & $\mathrm{V}$ & & \\
\hline & \begin{tabular}{|l|} 
Surat \\
\end{tabular} & & & & $\mathrm{V}$ & & \\
\hline & Laporan & & & & $\mathrm{V}$ & & \\
\hline \multirow[b]{4}{*}{ Penyesuaian Obat (stok opname) } & Query & & & & & & $\mathrm{V}$ \\
\hline & View & & & & & & $\mathrm{V}$ \\
\hline & Surat & & & & & & $\mathrm{V}$ \\
\hline & Laporan & & & & & & $\mathrm{V}$ \\
\hline \multirow[b]{4}{*}{ Pemesanan obat } & Query & & & & & & $\mathrm{V}$ \\
\hline & View & & & & & & $\mathrm{V}$ \\
\hline & Surat & & & & & & $\mathrm{V}$ \\
\hline & Laporan & & & & & & $\mathrm{V}$ \\
\hline \multirow[b]{4}{*}{ Pembayaran obat } & Query & & & & & $\mathrm{V}$ & \\
\hline & View & & & & & $\mathrm{V}$ & \\
\hline & Surat & & & & & $\mathrm{V}$ & \\
\hline & Laporan & & & & & $\mathrm{V}$ & \\
\hline
\end{tabular}


Tabel 2 Identifikasi Tipe Entitas

\begin{tabular}{|c|c|c|}
\hline Nama entitas & Deskripsi & Kejadian \\
\hline Pasien & Mendeskripsikan orang yang berobat pada klinik & Setiap Pasien melakukan satu atau lebih berobat \\
\hline Karyawan & $\begin{array}{l}\text { Mendeskripsikan karyawan klinik mencakup perawat, dokter, dan lain - } \\
\text { lain }\end{array}$ & Setiap Karyawan melakukan satu atau lebih transaksi pada klinik \\
\hline $\begin{array}{l}\text { Pemasok_Ob } \\
\text { at }\end{array}$ & $\begin{array}{l}\text { Mendeskripsikan external yang memproduksi Obat dan memasok ke } \\
\text { klinik }\end{array}$ & Setiap Pemasok memasok satu atau lebih Obat ke klinik \\
\hline Obat & $\begin{array}{l}\text { Mendeskripsikan Obat yang digunakan dokter untuk menyembuhkan } \\
\text { pasien }\end{array}$ & Setiap Obat dapat dijual ke satu pasien atau lebih \\
\hline $\begin{array}{l}\text { Pemeriksaan } \\
\text { Pasien }\end{array}$ & $\begin{array}{l}\text { Mendeskripsikan pencatatan transaksi pemeriksaan pasien selama di } \\
\text { klinik }\end{array}$ & Setiap pemeriksaan dapat dilakukan terhadap satu pasien atau lebih \\
\hline Tebus_Obat & Mendeskripsikan penebusan Obat sesuai resep & Setiap penebusan Obat dapat dilakukan terhadap satu Obat atau lebih \\
\hline $\begin{array}{l}\text { Penyesuaian } \\
\text { Obat }\end{array}$ & $\begin{array}{l}\text { Mendeskripsikan pencatatan data stok jumlah Obat sesuai dengan } \\
\text { hitungan fisik jumlah Obat }\end{array}$ & Setiap penyesuaian Obat dapat dilakukan terhadap satu Obat atau lebih \\
\hline $\begin{array}{l}\text { Pemesanan } \\
\text { Obat }\end{array}$ & $\begin{array}{l}\text { Mendeskripsikan pemesanan obat kepada Pemasok_Obat untuk Obat } \\
\text { yang sudah minimum stok }\end{array}$ & Setiap pemesanan Obat dapat dilakukan terhadap satu Obat atau lebih \\
\hline $\begin{array}{l}\text { Pembayaran_ } \\
\text { Obat }\end{array}$ & $\begin{array}{l}\text { Mendeskripsikan pencatatan transaksi penebusan dan penjualan Obat, } \\
\text { maupun pembayaran Obat ke Pemasok_Obat }\end{array}$ & $\begin{array}{l}\text { Setiap pembayaran Obat dapat dilakukan terhadap satu penebusan } \\
\text { Obat atau lebih }\end{array}$ \\
\hline
\end{tabular}

Tabel 3 Identifikasi Tipe Hubungan

\begin{tabular}{|c|c|c|c|c|}
\hline Nama entitas & Multiplicity & Hubungan & Nama entitas & Multiplicity \\
\hline \multirow[b]{3}{*}{ Pasien } & $1 . .1$ & Melakukan & Pemeriksaan_Pasien & $1 . .^{*}$ \\
\hline & $1 . .1$ & Melakukan & Tebus_Obat & $1 . .^{*}$ \\
\hline & $1 . .1$ & Melakukan & Pembayaran & $1 . .^{*}$ \\
\hline \multirow[b]{5}{*}{ Karyawan } & $1 . .1$ & Melakukan & Pemeriksaan_Pasien & $1 . .^{*}$ \\
\hline & $1 . .1$ & Melakukan & Tebus_Obat & $1 . .^{*}$ \\
\hline & 1.1 & Melakukan & Penyesuaian_Obat & $1 . .^{*}$ \\
\hline & $1 . .1$ & Melakukan & Pemesanan_Obat & $1 . .^{*}$ \\
\hline & $1 . .1$ & Melakukan & Pembayaran & $1 . .^{*}$ \\
\hline \multirow[b]{2}{*}{ Pemasok_Obat } & $1 . .1$ & Menerima & Pemesanan_Obat & $1 . .^{*}$ \\
\hline & $1 . .1$ & Menerima & Pembayaran & $1 .{ }^{*}$ \\
\hline \multirow[b]{4}{*}{ Obat } & $1 . .1$ & Dilibatkan & Pemeriksaan_Pasien & $1 . .^{*}$ \\
\hline & $1 . .1$ & Dilibatkan & Tebus_Obat & $1 . .^{*}$ \\
\hline & $1 . .1$ & Dilibatkan & Pemesanan_Obat & $1 . .^{*}$ \\
\hline & $1 . .1$ & Dilibatkan & Pembayaran & $1 .{ }^{*}$ \\
\hline \multirow[b]{5}{*}{ Pemeriksaan_Pasien } & $1 . .1$ & Melibatkan & Pasien & $1 . .^{*}$ \\
\hline & $1 . .1$ & Melibatkan & Karyawan & $1 . .^{*}$ \\
\hline & $1 . .1$ & Melibatkan & Obat & $1 . .^{*}$ \\
\hline & $1 . .1$ & Melibatkan & Tebus_Obat & $1 . .^{*}$ \\
\hline & $1 . .1$ & Melibatkan & Pembayaran & $1 . .^{*}$ \\
\hline \multirow[b]{5}{*}{ Tebus_Obat } & $1 . .1$ & Melibatkan & Pasien & $1 . .^{*}$ \\
\hline & $1 . .1$ & Melibatkan & Karyawan & $1 . .^{*}$ \\
\hline & 1.1 & Melibatkan & Obat & $1 . .^{*}$ \\
\hline & 1.1 & Melibatkan & Pemeriksaan_Pasien & $1 . .^{*}$ \\
\hline & $1 . .1$ & Melibatkan & Pembayaran & $1 .{ }^{*}$ \\
\hline \multirow[b]{3}{*}{ Penyesuaian_Obat } & 1.1 & Melibatkan & Karyawan & $1 . .^{*}$ \\
\hline & $1 . .1$ & Melibatkan & Obat & $1 . .^{*}$ \\
\hline & $1 . .1$ & Melibatkan & Tebus_Obat & $1 . .^{*}$ \\
\hline \multirow[b]{4}{*}{ Pemesanan_Obat } & $1 . .1$ & Melibatkan & Karyawan & $1 . .^{*}$ \\
\hline & $1 . .1$ & Melibatkan & Obat & $1 .{ }^{*}$ \\
\hline & 1.1 & Melibatkan & Tebus_Obat & $1 .{ }^{*}$ \\
\hline & $1 . .1$ & Melibatkan & Penyesuaian_Obat & $1 . .^{*}$ \\
\hline \multirow[b]{6}{*}{ Pembayaran_Obat } & $1 . .1$ & Melibatkan & Pasien & $1 .{ }^{*}$ \\
\hline & $1 . .1$ & Melibatkan & Karyawan & $1 .{ }^{*}$ \\
\hline & 1.1 & Melibatkan & Obat & $1 .{ }^{*}$ \\
\hline & 1.1 & Melibatkan & Pemasok_Obat & $1 . .^{*}$ \\
\hline & 1.1 & Melibatkan & Tebus_Obat & $1 .{ }^{*}$ \\
\hline & $1 . .1$ & Melibatkan & Pemesanan_Obat & $1 .{ }^{*}$ \\
\hline
\end{tabular}




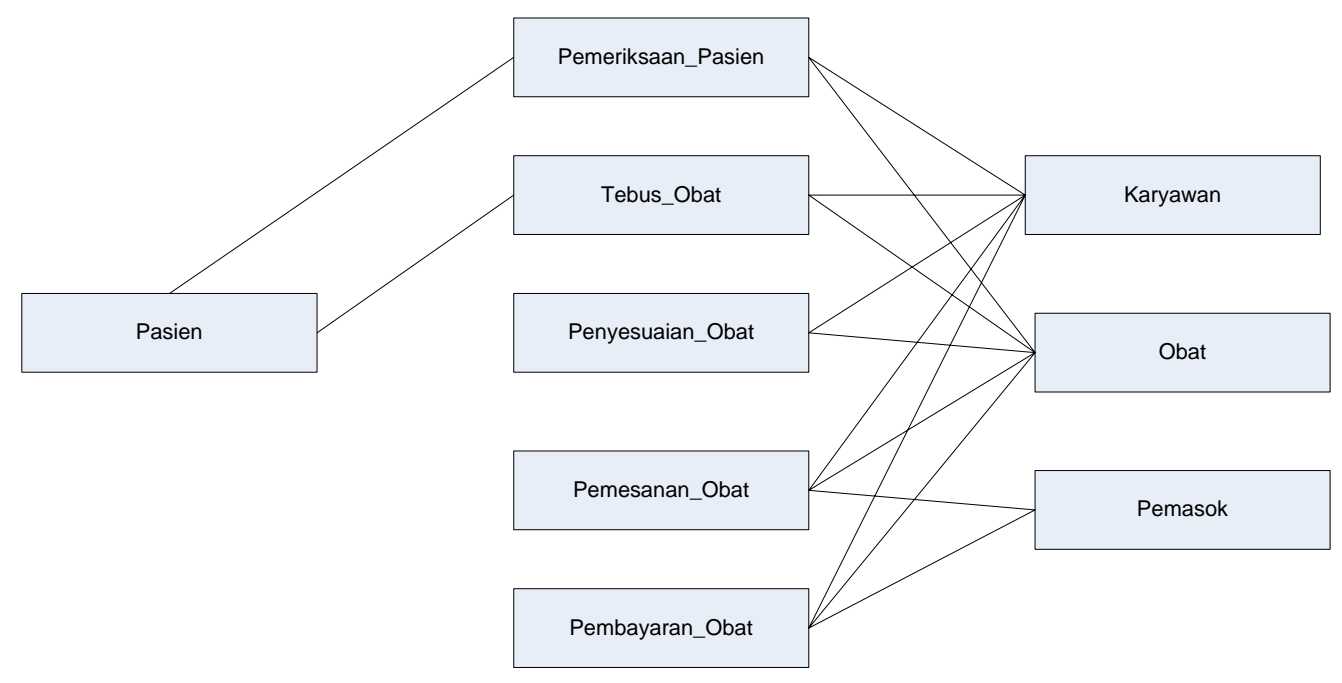

Gambar 3 ERD Konseptual awal

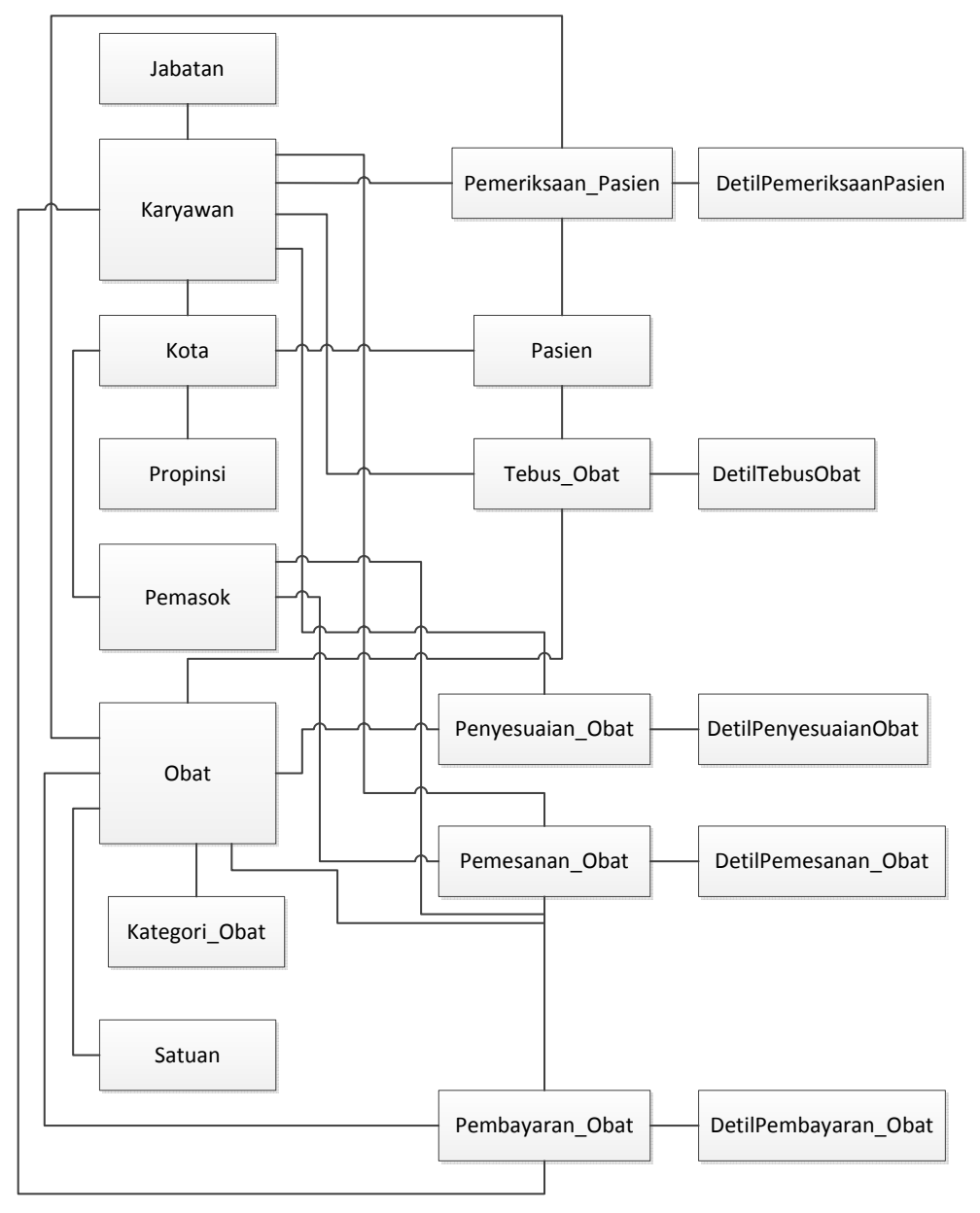

Gambar 4 ERD Logikal 